\title{
The Impacts of Civil-Military Cooperation Programmes on Human Security and Peacekeeping in Timor-Leste
}

\author{
Jessica Ong Hai Liaw, Guido De Oliveira, W.L. Wong, \\ Syed Azuan Syed Idrus and Nurul Faezah Mohd Talib \\ Faculty of Defence Studies and Management, National Defence University of Malaysia
}

\begin{abstract}
:
Civil-Military Cooperation (CIMIC) between two countries is based on the law and regulation of each country in order to achieve respective national political goal and agendas. In this case study, the Democratic Republic of Timor-Leste (or well known as "Timor-Leste") nation state which was established on $28^{\text {th }}$ November 1975 and the formation of the nation was the results of persistent and struggle of the people. They had struggled for as long as 450 years before obtained united, independent nation and sovereignty. After nine days of independence, on the $7^{\text {th }}$ December 1975, Indonesia asserted that Timor-Leste was the $27^{\text {th }}$ province of the Republic of Indonesia. This incident took place after the withdrawal of the Portuguese colonies. However, Timor-Leste restored their independence on $20^{\text {th }}$ May 2002 which was after 25 years of Indonesian occupancy. In this context, United Nations (UN) internationally recognized Timor-Leste as sovereign State and thereafter the $192^{\text {th }}$ member state of the UN. The study is limited to the impacts of CIMIC programmes towards the Timor-Leste people. Besides that, limitation of data collection has emerged due to ADF's reluctance to provide details and information which is related to the programmes conducted in certain period of time which has taken place from 1999 to 2006. This research is significant on the issues of human security, peacekeeping and CIMIC programmes in Timor-Leste. The lessons learnt from the ADF operations in Timor-Leste which could contribute to the policy planners of humanitarian interventions in other missions ahead in the future.
\end{abstract}

Key words: Civil-Military, human security, peacekeeping, humanitarian, interventions

\section{INTRODUCTION}

Civil-Military Cooperation (CIMIC) refers to the cooperation of both entities during a military mission. However, the classical discussion about CIMIC is referred to the party who should lead a state's armed forces, either civilians or military [1]. The relevant analysis which derived from relationship between military and civilian organizations is not only limited to merely any missions. Rebrand of methods and policies must be discussed for CIMIC to improve the outcome of peace enforcement missions and traditional peacekeeping. Therefore, the concepts of approaches are focusing on the aspect of human security as well as its application on East Timor Defence Force (ETDF)'s CIMIC efforts today. On the other hand, the concept of human security is also significant in the study regarding CIMIC. The strengths and weaknesses are not the only important areas to understand CIMIC's effects. It is also needed to show the way it appears and political advancements that activated the evolution. During the 1990s, United States and Russia changed their security policies where the nature of the international peace mission had changed and new political concepts were developed, for instance, the human security concept. Despite internal and external factors during the Cold War era, the international arena was mainly dominated by major world powers such as the United States and Soviet Union. Thus, interests in political, basic rules of security had to be polished after the change of perceived danger due to the end of the bipolar world and the fall of the Berlin Wall. In this context, Mathews has stated that global developments now suggest the need for another broadening definition of national security [2]. A new definition of security is required because new threats are emerging and 
could cause tremendous consequences to the populations in the region.

\section{PROBLEM STATEMENT}

There is insufficient of documented information regarding the extent of CIMIC approach applied by the Australian Defence Force (ADF) in the 1999 under cooperation between the International Force in East Timor (INTERFET) and United Nations Transitional Administration in East Timor (UNTAET). Meanwhile, Operation Astute is the ADF contribution upon a request from the Government of Timor-Leste in restoring peace and stability since the 2006 military interventions in the nation [3]. Therefore, the problem statement involves how CIMIC, human security, and peacekeeping are interrelated and what are the impacts of CIMIC activities on human security? Has ADF's CIMIC approach which was applied in the military interventions at Timor-Leste in 1999 and 2006 achieved the intended results? This study therefore is undertaken to fill this knowledge gap. It is imperative to study the CIMIC approaches which have been deployed by the ADF in Timor-Leste, specifically the assistance from ETDF in order to support the Timorese people in term of over human security issues.

\section{LITERATURE REVIEW}

The purpose of this section is to explore some of the literature relating to CIMIC and human security as far as Timor-Leste is concerned. It also intends to discuss different opinions, judgments and views of different scholars which are related to CIMIC and human security in Timor-Leste. Several books and publications exist regarding the subject, nevertheless very few analyses the operations conducted by the ADF and ETDF CIMIC programmes, and the impacts on the human security concern. Nevertheless, there are several journals and articles have written on the subject which is relevant to this study. Ian Flawith has written an article in Australian Journal of Multi-Disciplinary engineering, arguing the importance of ADF in undertaking CIMIC activities for better reconstruction of Timor-Leste after the conflict [3]. $\mathrm{He}$ argues that the ability to properly interact with International Governmental Organisations (IGOs) and International Non-Governmental Organisations (INGOs) in ADF area of operations. The author emphasizes that IGOs and INGOs, with the coordinated and synchronized actions between ADF assets, could realise a greater reconstruction and relief effort and non-kinetic effects could be generated swiftly on a large scale [4].

Rizal Sukma has described his perception in the Council for Asia-Europe Cooperation Journal regarding the professional behaviour of ETDF after independence was obtained. He is concerned of the history that any country emerges from the consequences of armed conflicts would face challenges in the context of CIMIC, especially the civilian's control of military [5].

The major factor for such challenges is that the party who involved in the armed sacrifice insists their special role to be recognised. Therefore, there is extravagant concern on making the former guerrilla fighters in the national army to work professionally and not interfering the politics of the newly established nation state. Therefore, the previous experiences of ADF which gained from the democratic institutions plays a key role in mentoring the new ETDF in promoting CIMIC and confidence building of the Timorese people. Therefore, urge for a closer CIMIC, especially between military and humanitarian agencies. They argue that the reason of the humanitarian space is increasingly more complex due to changing nature of conflicts and CIMIC. Hence, both the military and humanitarian agencies can achieve mutual benefits when cooperation is promised [6].

Brendan Howe highlights that Timor-Leste has achieved some degree of improvement in the aspects of human security and state building. Nevertheless, challenges remain due to the legacies of conflict and colonialism. Like other conflict-affected-states, Timor-Leste experiences economics progress and downturn [7]. However, when compared to other UN missions, Timor-Leste could be regarded as a success story as far as restoring human security was concerned. On the other hand, Timor-Leste still has tremendous room for improvement in terms of broader definition of human security. Currently, human security in the aspect of political equation has been achieved, despite gradual progress on economic, food and energy security. In the above findings from previous writings of researchers, it is agreeable that CIMIC is very crucial in establishing civilian control over the military, supporting the intheatre commanders to link with humanitarian agencies in the conflict zone, and improve the human security sector. Majority suggestions are regarded to ETDF needs to be deployed professionally and to improve CIMIC in order to protect the new nation's democratic institutions and to build confidence amongst the Timorese people. However, there is insufficient research is accomplished to evaluate the role of $\mathrm{ADF}$ and its contribution in mentoring ETDF in CIMIC efforts. It's upon this, which this research intends to fill this research gap. 


\section{IMPACTS OF ADF CIMIC APPROACH ON HUMAN SECURITY}

Analysis regarding ADF on their possible impact on human security in CIMIC that took place at TimorLeste from 1999 to 2006 will be studied by emphasizing the programmes that have been conducted. In this context, human security is defined as 'freedom from want' and 'freedom from fear'. It is categorized into three groups of partners which include the political elites, military and citizenry. Figure 1 demonstrates the illustration of the three partners which derived from Clausewitz Trinity. This could be narrowed down into planning level and subsequently to implementation of CIMIC itself.

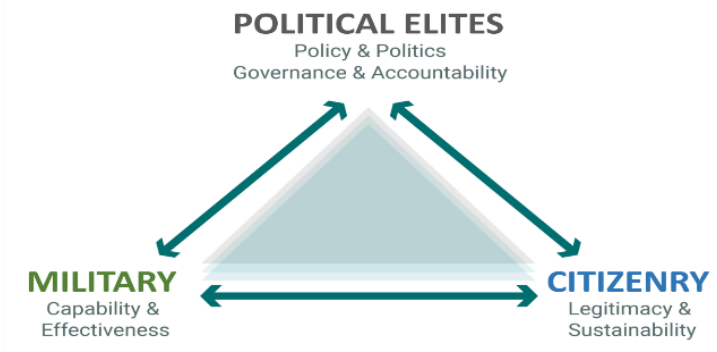

Figure 1: Interrelations of the Three Partners of CIMIC

The three partners play their important roles in achieving the core objectives. CIMIC in the context of human security emphasizes the influence of policy and politics practiced by the political elites, capability and effectiveness of military, as well as legitimacy and sustainability of the citizens.

\section{Political Elites}

In the time of wars, political elites are undertaken through the enforcement of one's own will. For Clausewitz, 'war is a mere continuation of politics by other means' [8]. The achievement of peace is the objective of war which is parallel with the national interests. War starts with the declaration proclaimed by the political class who also implement it. Therefore, the political class played an important role in defining general actions and the military's capacity to act.

Politics are crucial when negotiation practice is discussed, as well as establishment and equipment of the peacekeeping forces and the CIMIC units. These programmes are the responsibility of the government and it is represented when coordination with military leaders occurred. In addition, cooperation between military forces and their government involve politicians at the decision and policy making levels. The ultimate aim thus falls in the hands of the political elites.

As mentioned early in this paper, the Australian Defence Policy (ADP) subscribe a 'forward defence approach' where Australian's military operations deployed at neighbouring region as well as other parts of the world where its interests are at stake. Australian foreign and defence policy tend to be designed to contribute to security issues at global and regional levels, with the expectation that this will result in a safer world system, bringing flow-on benefits for Australia's interests [9]. In this context, ADP enables the government to deploy military forces, OGAs and NGOs abroad. The ADP can justify the humanitarian assistance deployment beyond Australia. Finally, this would lead to the deployment of troops and equipment to a successful civil-military operational readiness for the purpose of Timor-Leste's independence. In 2008, the establishment of ACMC in recognition of the growing importance of civil-military interaction is seen as the evidence of Australia's commitment to sustainable peace and prosperity in the Asia-Pacific region and beyond [10].

\section{Military}

In the context of national sovereignty, independent nations would be reluctant to permit any intervention of foreign military forces in their internal affairs of states. It might be a propaganda for the nation that invites foreign military intervention. Thus, military is considered the strategic assets of the nation to defend the national sovereignty of a country. However, with the evolution of the military function as a government tools to win the hearts and mind of the people, it is a very successful approach in their mission in the postWorld War II era.

The ADF was responsible for nearly all the logistics management in Timor-Leste during the first weeks of the military intervention. Thus, they were responsible for the major supply chain of the soonto-be independent nation. The airport was controlled by the military to ensure goods and other supplies safely entered Timor-Leste via this airport. ADF aimed at improving the security environment of the local people. Therefore, the willingness to cooperate with other humanitarian agencies and private organisations was vital for promoting the level of human security of the Timorese people.

The ADF contributed mainly by helping internally displaced persons (IDPs) and refugees to return safely to their home, as well as building refugee camps. As a result, it could be said that on a tactical level, had contributed to an increase of human security sentiment of the East Timorese people. The 
factor of success in the often ad-hoc-based CIMIC operations was the individual skills and capacities of the soldiers who had participated the operations.

\section{Citizenry}

Human security approach is an important tool to determine the level of success of governments in order to satisfy the needs and interests of their citizens. It also determines whether social and economic policies in weak and vulnerable societies are just and fair, inclusive and open [11]. Military represents the most trusted organisation to the civilians. Since the WWII era, military forces have become the organisation that protect the interests of the nation as well as the people. Military forces work hand in hand with civilian who function as the "eyes and ears" for the nation. The relationship between military and civilian has historical value that encourages the military to conduct humanitarian assistance and CIMIC programmes.

The achievement of human security is contributed by CIMIC as a peace building tools. The crucial aspect of human security element is the protection from physical violence in fulfillment of the" freedom from fear" as proposed by the UN. CIMIC is interpreted as a mechanism which is designed to minimize casualties and possesses the goal to protect civilians and military personnel from physical damages. In this case study, ADF and allied forces successfully restored security in Timor-Leste shortly aftermath the intervention. The victory was achieved due to the tactical and technical superior of ADF troops over the opponent. Different strategies were applied to prevent and overcome the recurrence of violence, thus promoted the peace building process. The ADF successfully determined the parties who were responsible for certain particular tasks in order to restore peace and enhance human security of Timor-Leste.

The ADF CIMIC approach in Timor-Leste has contributed to humanitarian action in line with its mandate and within force capabilities regarding human security's priority of "freedom from want". Force protection continued being the commanders' primary objective with CIMIC only being a secondary goal aimed at supporting the troop's mission to grant security, even if humanitarian assistance was part of the mandate. Thereby, local people were empowered too and ideally enabled to be responsible to their own security in long run. There, this was another key objective of the Human Security approach.

\section{IMPACTS OF ETDF CIMIC APPROACH ON HUMAN SECURITY}

Beginning with a referendum on independence in 1999 , there was a long involvement of the UN in the creation of the Timor-Leste nation which led to formal independence in May 2002. Timor-Leste is in certain ways, more forgiving and more welcoming than other contexts in which the UN has had a sustained peacekeeping, governance or humanitarian roles. From that starting point, there has been many events occurred and benefited the country as lessons learnt. By using the same category mentioned in the previous chapter, the three description of the impact is based on political elites, military and citizenry, as suggested by Carl von Clausewitz.

\section{Political Elites}

The Democratic Republic of Timor-Leste made its official entry onto the world stage with complete independence on 20 May 2002. The new head of state was the Timorese President, Xanana Gusmão, whereas the head of government was Prime Minister Mari Alkatirix, who was drawn from the leader of the majority political party at the time of independence. The main duty of the first unicameral parliament was writing of a new constitution, and subsequently it has been charged with legislative duties and to act as a counterbalance to the power of the presidency and the government. Majority of the people suggested to remain familiar themes, including the official languages, the role of personalities, factionalism and rivalries, the lack of separation of powers, internal insecurity, a culture of violence and the neglect of justice. Notwithstanding, only a few of these were acknowledged at the time. There could be many perceptions in a way on how the political success to lead the government of Timor-Leste.

The "Force 2020" was established on 11 June 2008, which integrating direct administration of the Timor-Leste within the scope of Secretary of State for Defence to establishing its competences under Article 11 and 23 of the Organic Law for the Ministry of Defence and Security [12]. Considering the width and nature of the agencies and entities involved in the reorganisation of the ETDF, the Force 2020 process has been compliant to the guidelines that apply political measures and military measures.

The political elites have driven ETDF role of civilmilitary cooperation as well as humanitarian as supported by Article 5 and 23 of the National Defence Law. The Law has highlighted that the military's critical role in supporting the community's social, economic development and 
implementing the state's foreign policy abroad [12]. This has been a major focus of the ETDF since 2007 and the capacity of the force to independently undertake these missions has increased dramatically over the past few years. This is due to significant interaction with both the ADF, as well as the military forces of Malaysia and the United States.

\section{Military}

The impact of ETDF CIMIC approaches toward human security could be seen in many other programmes aftermath the 2006 intervention. ETDF has undertaken a number of Medical Civil Action Programmes (MEDCAPS) since early 2010. These programmes involve operational teams from ETDL and Ministry of Health travelling to remote areas of Timor-Leste, where the people hardly receive regular access to healthcare, to provide mobile medical clinics. These mechanisms are supported by the ISF and Defence Cooperation programmed whom provide mentoring and planning assistance. These mobile clinics are overwhelmingly popular and regularly see many local people are treated by the ETDF medics and Ministry doctors. These programmes could be said as the collaborative effort that generates high impacts.

These small scale -programmes have attracted the attention of the US Navy's Mercy hospital ship, and a multilateral exercise known as Exercise Pacific Partnership was conducted. The hospital ship docked in Dili and joint teams of the US, Australia and ETDF medics flew to areas such as the Oecussi enclave, Laclubar and Remexio to conduct large scale MEDCAPS. In the time frame of two weeks, the teams treated more than 20,000 patients and conducted 175 surgeries. The team was made up of the combination of ETDF infantry and signalers who provided logistics, security, interpreting and liaison support to the medical team's efforts [12].

ETDF has also increasingly placed its focus on providing engineering support to the local community, particularly participated in the Pacific Partnership humanitarian activity. The engineers worked with the US Navy and Australian Army to rebuild a school in the Dili suburb of Nuu Laran. These engineering taskforce has been working with its international partners since 2008, and has prepared the ETDF to conduct Engineering Civil Action Programmes (ENCAP) independently.

\section{Citizenry}

The Ministry of Labour and Community Reinsertion (MTRC), with the support of the International Organisation for Migration (IOM), UNDP and OCHA, have established an Information Centre to collect and share information on the humanitarian operations. In this regards, MTRC coordinates the humanitarian response through the Humanitarian Coordination Group, which later became the InterAgency Humanitarian Assistance Group.

Aid agencies always focus on the condition of IDPs, where the priority is to ensure that they could be moved out of overcrowded and unsanitary makeshift camps into areas that would also provide protection to women, children and the elderly. However, given the volatile security situation, it has become apparent very rapidly that relocation would have to be postponed. Therefore, the subsequent focus has been shifted to improving conditions in the refugee camps. Another factor that aid assistance is essential in Timor-Leste is that its birth rate is one of the highest in the world, where mother and child care are imperative. Food, clean water and shelter are identified as the priority needs. The impact shows positive outcome from the citizens on CIMIC and humanitarian assistance provided in the targeted

\section{IMPACTS OF CIMIC IN PEACEKEEPING}

The term "peacekeeping" refers to the mobilisation of national or multinational team more generally to help control and resolve armed conflicts that are actual or potential between or within the state [13]. Military peacekeeping forces often are deployed with the consent of the parties to the conflict zones, and support the ceasefire or peace action agreed upon another. Generally, peacekeeping forces are unarmed or only lightly armed, and use minimum of force when necessary and exceptional.

Peacekeeping is an approach to help countries which torn by conflicts to improve conditions for sustainable peace. It is widely known that peacekeeping operation is deployed under the command of UN peacekeeping mission. Today, contemporary peacekeeping operations are not only deployed to maintain peace and security, but also to facilitate political process, protect the public, assist in disarmament, system and reintegrate the former combatant, to support the organisation, protect and promote human rights and to restore the rule of law. UN Under-Secretary-General for Peacekeeping Hervé Ladsous has stressed that "beyond the 'traditional' roles of monitoring cease fires and deterring the eruption of violence, peacekeepers now have direct support to peace processes in the post conflicts, such as to reform of rule of law, support to elections processes, justice and corrections institutions, diseases awareness-raising, promotion of human rights and women's empowerment and civil-military coordination like protection of children and other vulnerable populations [14]. 
In peacekeeping operations, it should be made clear that the military peacekeeping component is not a solution to the conflict. Thus, by understanding the nature of the conflict, roots and causes of the conflict could help in resolving the existing conflicts. Hence, the end state is usually a political element whereby the conflicting parties themselves should resolve by gaining support from the international community.

Peacekeeping efforts in the modern days have evolved into a complex, multifunctional and multidimensional characteristic. Contemporary peacekeeping operations not only bring together people of different backgrounds, but also include various organisation which leads to greater interactions. And, thus challenges in cultural interaction are created. The principles of peacekeeping elements have embarked in the "Capstone Doctrine" The Dotrine determines the organisation of planned peacekeeping operations in the future, and thus improve the coherence and cooperation towards interventions. Subsequently, cooperation between civil-military relations will also be achieved in order to further enhance the positive impact of peacekeeping operations and humanitarian programmes. It is necessary to enhance coordination of complexity among the proliferation of humanitarian actors in area of crisis [15].

Peacekeeping programme is essentially a CIMIC function as an interaction between the military and other organisations with a common aim. As such, to work effectively there is a need for a better integration which can only be realised through understanding and acceptance of cultural diversity. There are various CIMIC programmes involved in peacekeeping operations. Despite medical services provided, there are other CIMIC efforts, such as construction or maintenance of public facilities building, sport activities with the locals, and donations of computers and books to the local schools. Those activities have positive impacts towards winning the hearts and minds of the local population and this has been a defining factor of a successful operation [16].

Meanwhile in post-conflict societies, security officers must have individual responsibility to protect $(\mathrm{R} 2 \mathrm{P})$, respect and promote human rights, and recognise human rights mandate in their operations. The human rights problem needs to be address and considered in all levels and in all activities. Therefore, addressing human right problem is regconised as an essential aspect of finding solutions to conflicts. There are four articles of the Universal Declaration of Human Rights (UDHR) which assert the human rights issues during conflicts, including Article 3 on "The Right to Live
Free", Article 4 on "No Slavery", Article 5 on "No Torture", and Article 13 on "Freedom to Move" [17].

Political culture also possesses impacts towards the peacekeeping forces, own nation political agenda, the influence of own military command structures, influences of the Force Commander or even the local UN peacekeeping headquarter. The peacekeeping mission to Somalia, which termed UNOSOM II, is a good example to illustrate the impact of cultural diversity. It also showcases some measures adopted to reduce the effects of cultural diversity on the peacekeeping operations and efforts to stabilise the nation.

\section{CONCLUSION AND RECOMMENDATIONS}

CIMIC is a mechanism that involves a two-pronged relationship between the military forces and society. The objective of such programmed is to disrupt an activity that demonstrates the form of cooperation with civilian organisations, for instance the local authority, NGOs, Other Government Agency (OGA) and IGOs. In addition, this cooperation is commonly applicable when conflicts occur, despite the circumstances of the post-natural disaster, postwar and during the operation of peace support and tranquility.

The Timor-Leste conflicts started when offensive attacks were launched by the militants towards civilians to express their violence to the country. The offensive out broke when a majority of eligible voters of Timor-Leste chose to obtain independence from Indonesia. Thus, the involvement of the UN authorized forces, which mainly comprised of Australia Defence Force, were deployed to restore peace. The violence spread widely and anger rose among Australia, Portugal and other nations. Subsequently, international players decided to take necessary measurements. Hence, on 12 September 1999, Australia-led international peacekeeping forces entered Timor-Leste, despite the withdrawal of Indonesian soldiers.

ADF managed to implement various approaches to ensure the mission is achievable. In order to do that, the Concordance Theory is subscribed to analyse the ADF approaches with regards to human security mechanism, peacekeeping and CIMIC programmes in Timor-Leste. The theory concerns the political elite, military and citizenry as the core characteristics. At such, the purpose of establishment of "Force 2020" is to establishing its competences under Article 11 and 23 of the Organic Law for the Ministry of Defence. Thus, security was applicable and the application of political and military measures were essential. In the future, ETDF would be able to spark new plans that would 
be filling the gap from the ADF operations. The ADF are used as an example of these approaches because it is the first involvement for peacekeeping operations, and also brought independent for TimorLeste. Therefore, Timor-Leste could achieve selfsatisfaction at the same level with other countries in this region.

There are various lessons learnt in the path to TimorLeste independence from prolonged colonialisation by the Portuguese and Indonesia invasions. Below are some recommendations to enhance the capability of CIMIC in any operations.

i.Political elites play an important role in decision making process. Hence, the interaction between civilians and military forces are crucial. Moreover, the military shared the people's interest in promoting security and balance the economic situation for the host nation.

ii.Foreign Policy and Defence Policy are the policies that justify any reasons to deploy military personnel and assets abroad.

iii.Trainings are important elements of the military requirement for CIMIC. The military involved in CIMIC should have related training and skills before deploying for further CIMIC and human security programmes.

iv. CIMIC should be exercised domestically to meet the standard and also be part of the responsibility of military secondary task to assist the civilian agencies in the development of the people and country. v. Information gathering is important before CIMIC operations are conducted. Thus, this meet the requirement of the peoples and gives high impact to the trust of government.

\section{REFERENCES}

[1] Huntington. S.P. (1957). The Soldier and the State; the Theory and politics of Civil-Military Relations. Cambridge: Belknap Press of Harvard University Press.

[2] Mathews J.T. (1989). Redefining Security Foreign Affairs. Vol.68, No.2, pp.162.

[3] Australian Government Department of Defence. Retrieved on 5 June 2017 from the website http://www.defence.gov.au

[4] Flawith, I. (2008). Civil-Military Cooperation and the Australian Defence Force: A Reserve Capability. Australian Journal of MultiDisplinary Engineering, Volume 6, Issue 2.

[5] Sukima,R. (2001). Securing East Timor: The Military and External Relations. Council for Asia-Europe Cooperation, Jakarta.

[6] Morton, K.\& O’ hagen, J. (2009). Humanitarian and Civil-Military Relations in the Post 9/11
World. National Library of Australia, Department of International Relations, Canberra.

[7] Howe,B. (2013). Rebuilding Human Security in East Timur. Critical Studies of Asia Pacific Series on $5^{\text {th }}$ April 2017 in website http://link.springer.com/chapter/10.1057/9781 137293657_8\#.

[8] Clausewitz (1992). On war. (M.E. Howard \&P. Paret trans). New Jersey; Princeton University Press)

[9] Kilcullen, D. J. (2007). Australian Statecraft: The Challenge of Aligning Policy with Strategic Culture. Security Challenges, Volume 3, Number 4, pp. 45- 65.

[10] Australian Government Asia Pacific CivilMilitary Centre of Excellence (2010). Strengthening Australia's Conflict and Disaster Management Overseas. Retrieved on $18 \quad$ May 2017 from https://www.acmc.gov.au/wpcontent/uploads/ 2014/09/5176-CIVMILCOE-ConceptualFramework-Booklet-V6.pdf.

[11] Clarke, M. (2006). Aid in Conflict. New York: Nova Science Publisher.

[12] Pinto, J.T. (2012). Timor Leste Defence Development. Yogyakarta: Nuansa Pilar Media.

[13] United Nations (2008). United Nations Peacekeeping Operations: Principles and Guidelines. Retrieved on 5 May 2017 from http://www.un.org/en/peacekeeping/document s/capstone_eng.pdf.

[14] United Nations Department of Peacekeeping Operations and Department of Field Support (2012). Civil Affairs Handbook. Durban: United Nations Publication. Retrieved on 5 May 2017 http://www.un.org/en/peacekeeping/document s/civilhandbook/Civil_Affairs_Handbook.pdf.

[15] Koth, M. (2013). Civil-Military Cooperation and Its Impact on Human Security - Chances and Limits: The Example of the Australian Defence Forces in East Timor (1999 and 2006). IFHV Working Paper, Vol. 3, No. 1. Retrieved in 16 May 2017http:/www.ifhv.de/documents/workingp apers/wp31.pdf.

[16] Roslan (2011). MALBATT 3 di Bumi Lubnan: United Nations Interim Force in Lebanon (Januari - Oktober 2011). Books published for Joint Headquarters.

[17] Tae-Ung Bai k (2012). Emerging Regional Human Rights System in Asia. Cambridge: Cambridge University Press. 